\section{All the World's a Cage}

Veronika Schandl, Socialist Shakespeare

Productions in Kádár-regime Hungary:

Shakespeare Behind the Iron Curtain

(Lewiston: The Edwin Mellen Press, 2009)

Veronika Schandl's Socialist Shakespeare Productions in Kádár-regime Hungary was published at the end of 2008 by Edwin Mellen Press in English, a fact which immediately poses the question, "Is that of any interest for foreigners?" But in fact many more questions are triggered: is it not the business of the Hungarians? Is it not material which concerns solely the history and cultural history of Hungarians? Is it not a volume that should have been written in Hungarian for the sake of the Hungarian reading public?

Poet, translator and Shakespeare scholar István Géher asks the same in the Foreword of the volume, hence the quotation marks above. He also attempts an answer. "It should be," Géher replies. He adds, "in the post-modern world of relativity the 'doublespeak' and 'the reading between the lines' cannot be dismissed as mere provincial peculiarity" (ii). I agree: our students' generation meets only a faded memory or even less than that - a lack of record and of summary - about the theatre life of the era characterized by the unreliability of words and the swampy fields of doublespeak. We all hope these belong to the past. However, the post-socialist present often seems equally swampy an area. Surviving characters assuming active parts on the stage of Kádár-regime theatre life often are influenced by present day politics which may affect their work retrospectively. From a more distant perspective, for the sake of our students' generation(s), it is vital that the history of Kádár-regime (1956-1989) theatre be recorded.

Such a record assumes at least three things to be successful or worth mentioning: unearthing of state documents with significant knowledge of history, unceasing work with performance details and a relatively objective or at least emotionally uninvolved bird's eye view of the narrator. I found all these in Veronika Schandl's book, and I will approach them exactly from these angles in the following pages.

The author is the daughter of a set designer, to whom the book is dedicated. From this fact could follow that the book, under the same title, would turn out to be either a sorrowful lament over creative minds ruined and talented lives wasted, or a political pamphlet burdened with a disproportionate load of political history. Either would have been a pity and would not be equal to the task. To the great relief of the reader this book is not a pathetic monument, either historical or personal. What makes it valuable, both as a reading and as a useful basic entry on a university reading list, is the colourful and sensitive picture she presents. Here the word 
colourful refers to both the subject and the presentation of the work. The trap of false over-generalizations she easily avoids: by digging out a quantity of detail that itself earns respect, she manages to paint a tableau of each examined performance of the period. These, then, create the overall feeling which we often have when watching the busy crowds in action in one of the large oil paintings by Pieter Breughel the Elder. Interesting and perhaps even amusing in their minute details, the descriptions of each performance add up to a vast tableau of various and colourful groups of characters and scenes, inviting browsing and research.

Nonetheless, the latent fears, spies, double agents, denunciations and forced silences cannot be, and luckily are not, dismissed. Their representation is not reduced to a mere register of offences suffered by theatre intellectuals during the Kádár-regime. The book has no lament over missed past opportunities. Although opportunities all receive due mention and description, lament is left for the reader. And it is done well this way: the tone of the narrator is that of the attentive theatre historian, who is enthusiastic about the subject, its each and every detail. At this point a usual laudatory sentence would fit here: "Her well-documented tiny mosaic pieces are the result of persistent research executed on an impressive scale." Which translates, as all researchers know, into an awful lot of work. The balanced narration of this book appears to be objec- tive enough to suggest that the author's person was a contemporary of Socialism. However, Veronika Schandl (currently lecturer at Pázmány Péter Catholic University, Hungary) is much younger than that, which triggers ambiguous consequences. Thus she could have had first-hand information neither of the mechanisms, nor the machinations of Party-controlled Socialist culture. Also, her not being a contemporary could aid her in the assumption of a nearly omniscient and practically impartial bird's eye view.

Historiography always requires backing one's argument with facts and firsthand sources. In the historiography of an era through theatre performances, through perhaps the most ephemeral of subjects, details may mean much more than merely supporting some argument. Details here mean a great variety of contemporary sources, and they are generously provided so that the reader may see more of the entire picture than the actual focus of the theatre historian. Undoubtedly we would never see the entire picture; this is a puzzle which will never be complete. We must always remember, as the author's critical remarks also remind us, that no theatre criticism can ever be reliable, especially not when written in a dictatorship. Schandl's book offers a surprisingly round picture of the chosen performances firstly because of the high number of sources, and secondly because of her deep knowledge of these sources. They range from the reports 
and speeches at the first Soviet Writers' Congress by Zhdanov and Gorky (principal and obligatory directions for Hungarian artists as well), through Hungarian state security archives, to pieces of theatre criticism in both wellknown national papers like Népszabadság [Liberty of the People] and some impossible factory papers like Kazán [Boiler], paper of the smelters. It seems credibility and the truth of the overall picture, no matter how complicated it may be (think of the twisted story of the Hamlet directed by Gábor Bódy, who was both an agent reporting to the police and a subject for other agents to report on, cf. 45-65), matters more than anything to the author. The flexibility of her understanding of the complexity and the delicacy of certain political and personal situations in which Shakespeare was produced (see also the twists in the career of the great survivor chameleon actor Tamás Major, pp. 169-187) allows her a deeper understanding of the productions. A prerequisite for this is handling these sources with the necessary and often different distance. Due to Schandl's research, anyone who is to write the stage history of yet another Shakespearean play on Hungarian Socialist stages may rely on the sources she has unearthed as well as on her masterly executed historical background (never too little, never too much - even for foreigners.). Also, in her Breughel-like detailed tableau readers will find their favourite scene, best documented for their interest, which will enable them to draw their own conclusions.

All in all, a part on the historical and political back(or fore?)ground was an inherent necessity. Chapter 1 comprises the basic knowledge of cultural and political history for Hungarians and non-Hungarians equally: from those who have never been to Hungary, to Hungarians who were the audiences of those productions, to Hungarians who are too young to have lived in the era also known as 'Goulash communism,' and to anyone interested in the colourful impression of cultural life in a complicatedly and inscrutably softened version of Central-East-European Communist dictatorship and the self-suppressing atmosphere in the most cheerful of Soviet barracks.

This book is a careful compilation of performance criticism. First, of Hamlets and later, as the political atmosphere triggered, of problem plays. Veronika Schandl examined no less than 27 performances and their critical and political reception. In addition to the cast lists she also included a Chronology of the performances in the Appendices (A and B) - all very practical for a Hungarian reader and researcher. Again, is that of any interest to foreigners? Was it worth translating into English all those theatre criticisms published in some Socialist self- and peer-censored newspapers, remotely but strictly and unpredictably controlled by the omnipotent Party guru György Aczél? 
The answer is yes. These sources, outdated both in sense and style, embody a part of the Hungarian national past as well as of the very particular ways of communication in a Socialist satellite country. The late nineties and the early two-noughts are the period of setting things right in these countries, in this case by the remembrance and the description of Socialist years on the stage.

While providing the reader with a seemingly omniscient bird's eye view of the era and its theatres, the author never seems to appear. Nonetheless, Veronika Schandl's approach to Shakespearean performances and performance criticisms are sensibly ever present in the background. She managed to achieve the proportionate balance between the articulation of the narrator of past performances and that of her own opinion as a Shakespeare scholar. The result is not forgiving sympathy towards bad or didactic productions popular at the time, neither is it a flaming political flare against the Soviet regime. Her interpretations all point in one direction, towards Shakespeare's continuous position and presence in Kádárist Hungary.

$$
* * *
$$

Shakespeare, whose appropriation had been so significant for non-English, and particularly Central European countries in the nineteenth century, seems to guarantee the transfer of continuity of (high) culture from one regime to the other. Schandl's book is built upon the widely known and accepted fact that even the Socialist dictatorship wanted to appropriate the once capitalist entrepreneur Bard only to demonstrate its cultural strength, creativity and rule over intellectuals. Marxist Shakespeare was "praised for his critical treatment of the social ills in early modern society, in which his aim was not only to criticize the bourgeoisie, but to affirm the positive nature of human progress and firm optimistic belief in the future to come. ... The same way that Shakespearean plots were seen to parallel Socialist narratives, Shakespearean characters were viewed as early predecessors of the new Socialist hero, an active fighter for justice who never accepted compromises. .." (13). Hence just as a play holds mirror up to human nature so does the actual Shakespeare-cult to particular society in a particular period. The examination of an actual Shakespeare cult is thus definitely worthwhile. Thence Schandl's book must be placed alongside the accounts of other Shakespeare appropriations in the Eastern bloc (e.g., Shakespeare on the German StageThe Twentieth Century by Wilhelm Hortmann (1998), On Page and Stage: Shakespeare in Polish and World Culture ed. by Krystyna Kujawinska Courtney, Redefining Shakespeare - Literary Theory and Theater Practice in the German Democratic Republic by Lawrence $J$ Gunther and Andrew McLean (1998), etc).

The way Veronika Schandl found a gap among these writings and ventured to fill it in was writing about the presence of Hungarianized Socialist Shakes- 
peare: she reveals and points out the apparent ambiguities embedded in what she calls "the theatricality of everyday life" (9). Her book is an account of the sometimes desperate efforts of Kádárregime theatre-makers to respond to or hint at topical public discourses. "The aim of the work is not, primarily, to reconstruct these productions of the Kádár-regime, although it wishes to delineate the major theatrical trends of the era. Rather through contemporary reviews, articles and essays, as well as current historical data available about the theatrical structure and the culturalpolitical establishment of Communist Hungary, this study aims to examine the dialogues that connected theatres to the political everyday lives of Kádárist citizens" (14).

Regarding the overall picture, it was a sensible idea not to insist on the performance history of a single play, as well as to not analyse more than four. The suppressed and hesitating hero in Hamlet, and the relativity in the worlds of the problem plays, seemed best to represent the changes in the political climate. The era/history dictated: Hamlet was produced eight times, while Measure for Measure eight times, Troilus and Cressida five times and All's Well thrice, serving as the key texts that best suited the Kádár Era. The numbers show that Hamlet "remained a constant favourite" (along with the comedies). The author examines both the time pattern of all these productions related to Hungarian politics (certainly no Hamlets in the fifties after 1952; the first after the 1956 revolution was in 1963) and also, casts them against the backdrop of foreign theatrical influences either on the page or on the stage: those of Brecht, Peter Brook, Jan Kott, Grotowsky. She draws the picture of Hungarian productions from several aspects (which then all unite in the "theatricalities of everyday life"). Not only does she consider them from the aspect of their uses of the text, their modes of interpretation with respect to artistic influence, but also from their modes of existence. Mainstream, avant-garde and amateur theatres received different amounts of attention in their being monitored by State Intelligence. Although each chapter deals with either a play (the problem plays, Chapters 5-8) or a period (Hamlets, Chapters 2-4), the author manages to sketch the individual careers of several directors who moved from one kind of theatre to another, from one level of being monitored to another. Very importantly, she traces back the reasons for Paál's and Ruszt's tragic rise and fall, victims of "doublespeak" and "reading between the lines."

"What distinguishes the Hungarian Shakespeare repertoire from other Eastern European countries," writes Veronika Schandl - and she is a pioneer in noticing this- is the "unparalleled popularity of the problem plays in the theatrical canon of the 1970 and 1980 " (100). She goes on to explain: "The standards of living much higher than 
average for the eastern Bloc, spread the illusory sense of freedom in the everyday lives of citizens. At the same time ... the regime still did not tolerate overt opposition.” As Schandl explains, "directors in Hungary repeatedly saw a powerful tool [in Shakespearean problem comedies] to reflect on their lives, the perverse coexistence of good and bad in their political reality. Their shows became mainstream cultural events, ushering in a new Hungarian theatrical idiom, a changed concept of how Shakespeare should be performed" (100101).

No more fairy-tale productions of All's Well (like Várkonyi's direction in 1961), much rather as parables of self-delusion, no more "uplifting" and "optimistic tragedies.” Young directors came, and"all exhibited a more grotesque, at times even absurd, approach in their directions" (106). The Troilus and Cressidas in the 1970s and 1980s touched upon the "insanity of the Cold War and the segregation of public and private spheres," showed individuals who "carried on with their lives within the system, even after realizing its absurdity" (147). While explaining these processes the author simultaneously refers to achievements by academics: a direction of Troilus by university professor György Székely on the regime that never gives in; György Endre Szőnyi’s essay emphasizing the darkly grotesque, even absurd undertones, which referred to the intellectual crisis as theatre; theatre criticism and the influence of Shakes- peare scholarship must be considered in union. By the end of the Kádár-regime it was the Measure for Measures, Schandl reveals, that shed light upon a fundamental element of the regime. The consolidation of Kádárism, the hope of a new era at the price of a compromise, is demonstrated in Measure productions. Of Paál's 1985 Veszprém direction she wrote, "Isabella's defiant silence [in rejection of the Duke] did receive an extra, thoroughly political connotation through the cultural, political and social surroundings of contemporary Hungary, a culture highly sensitive to forced silences, doublespeak and the interpretative technique of 'reading between the lines' " (160). However, I found it important that Veronika Schandl points out the fact that "the allowance of 'doublespeak' was an essential part of the Faustian deal artists made with those in power. The 'doublespeak' of the stage lured people into the false sense of freedom controlled by the companies themselves, most by means of self-censure. ... The theatre created an almost pathological audience-actor relationship in which the former awaited subversion and the latter was all too willing to provide it" (175).

To both illustrate and demonstrate the operation of 'doublespeak,' Veronika Schandl turned to a poem by Géza Bereményi, sung by Tamás Cseh in the early 1980s, The Song of Wiley William. ${ }^{1}$ What she found in it was inspiration, emblematic, even iconic lines for 
Hungarian readers, perfect metaphors of/about the era for foreigners, and an imprint of the Hungarian Shakespeare cult ("in this picturesque country show me a man, / who could compete with Shakespeare William”). A perfect example of the practice of 'doublespeak' and 'reading between the lines.'

Quite fortunately, she recognized the weight of the song as well as its potential metaphoric significance within the book and had a young poetess, now a University of East Anglia PhD graduate, Ágnes Lehóczky, translate it. With or without prejudices about the feasibility of such a translation, foreigners and Hungarians will find it witty, sensitive, easy to sing, and all in all, surprisingly good. The poem on the fifth page not only contributes to the atmosphere of the age as a longish motto, but also serves as a governing principle and a structuring force in the book: its lines reappear in the metaphoric and also allegorical chapter titles, adding a special Eastern Bloc flavour to the production analyses. Moreover, they present the reader with a first-hand experience of reading between the lines. Both the stage history of Hamlet and that of the problem plays perfectly suit Bereményi's lines (no wonder, as Bereményi himself authored an adaptation of the play entitled Halmi or the Prodigal Son, also examined by Schandl). Let me quote some of them: “ 'The world's back is curved': Shakespeare in Socialist Hungary" (Chapter 1), “ 'To cover dark secrets he acted a fool': Hamlet on Hungarian stages between
1952-1977” (Chapter 2), or “ "Which grave as you see, is our stage prop today': Hamlet on Hungarian stages between 1981-1983" (Chapter 3), or, " 'What vast labyrinths zigzag in our hearts': Troilus and Cressida in Late Socialist Hungary" (Chapter 7) and " 'We look for the keys, for clues and for hints': Measure for Measure in late Socialist Hungary" (Chapter 8), etc. Nonetheless, as generations grow up reading this (which I hope will happen), clauses of this kind in the body text “especially after Stalin's death” (14) will need more and more annotation to be added in the next edition; here I only missed the date, yet for the sake of young Hungarians and foreigners a review of such perspective could be vital. The dialogue of this text, at which the author aimed, works in both directions: between Hungarian theatres and everyday reality and also between Hungarian and foreign theatrical trends. "By the rule of the theater which converts all past modes into stage presence, our past becomes our present. The mockery of our cultural past, in turn, not only casts a dubious light on ancient heroic times but also on the centuries of European cultural development, an idea which could also threaten the logic of Marxist teleological historical ideology. Equating the caricature of the past with the present at the same time also allows for analogies between onstage and offstage reality. .." (134).

The mosaic is quite full, the "chippings of our scattered mirrors / are 
mended" in this volume (v). "I wish to recommend this book on Shakespeare," wrote István Géher in the Foreword, "to the inquisite consciousness and alert conscience of both Hungarian and nonHungarian readers." So do I. Yet I think many others would be interested in reading this book in Hungarian.

Gabriella Reuss

\section{Note}

1. The following excerpts serve as eminent illustrations: "Oh why can't you see what vast labyrinths / zigzag in our hearts with no directions / we look for the keys, for clues and for hints / staring into our own trembling reflections... // here we are standing in awe of the man / in front the greatness of Shakespeare William" (translated by Ágnes Lehóczky).

\section{"Only Connect!" Zadie Smith Convenes Critical Minds}

Tracey L. Walters (ed.), Zadie Smith: Critical Essays (New York: Peter Lang, 2008)

With intertextuality as a central concern in this exploration of the fiction of a contemporary, biracial, Englishspeaking and internationally acclaimed novelist, the idea of texts in interaction also asserts itself on the level of related critical discourses. The reader easily gets the impression that, while part of the book is about Zadie Smith, another, just as important part, is about recent devel- opments in literary scholarship. Yet this additional function of the collection as a kind of postcolonial reader - with its heavy concentration on theory - does not mar the accessibility of the text, and one can only profit from simultaneously learning about Smith's writing, and about current insights in contemporary, especially post-colonially attuned, literary interpretation.

On account of this exuberance of critical slants (and a kind of copious, exuberating quality in the author's fiction itself), the division of the volume into two appears to be a little forced, a mere gesture to provide a larger structure. The first section promises postcolonial and postmodernist readings of the related novels, and the second announces a primary concern with racial identities. This separation not only omits consideration of the overlap between these broad categories but it also fails to designate - even on the condensed, metaphorical manner in which most titles anticipate certain contents - the actual subject matter of a few chapters. Thus, the fifth essay about White Teeth as a Caribbean novel could easily be shifted from the first section into the second, because while its focus is on a kind of reversed colonial process, it prioritizes the category of race and ethnicity. Conversely, the twelfth paper, the final paper, on the international marketing of the same novel might just as legitimately be treated in the preceding unit about postmodernism, because it is much less geared towards a discussion of race than 